\section{Shakespeare and Company}

Brian Vickers, Shakespeare, Co-Author: A Historical Study of Five Collaborative Plays (Oxford: OUP, 2002)

Brian Vickers does not mince words. The very first sentence of the preface to Shakespeare, Co-Author comes right to the point: "This book asks the question 'How much do we know about Shakespeare's collaboration with other dramatists?', and tries to extend that knowledge" (vii). Over the next 500 pages, he describes just how much we should already know about this collaboration, discusses how both Shakespeare's conservators and his post-modern critics have ignored, misunderstood or misrepresented the evidence of it, and demonstrates that 5 plays in the canon were indeed written with another author.

Vickers, currently a senior fellow at the School of Advanced Study, University of London, was for many years a professor of English literature at the Swiss Federal Institute of Technology in Zurich, and also directed its Centre for Renaissance Studies. He has been publishing since the 1960's; in addition to work on Shakespeare, he has written on Francis Bacon, rhetoric and Greek Tragedy. Two of his most important contri-

The views expressed in the book reviews do not necessarily reflect the opinions of the editors of The AnaChronisT. butions to the study of Shakespeare until now have been Shakespeare: The Critical Heritage, 1623-1901 ${ }^{1}$ and Appropriating Shakespeare: Contemporary Critical Quarrels. ${ }^{2}$ The editing of the former confirmed Vickers as a historian of the first rank; the writing of the latter solidified his reputation as the most outspoken and erudite, critic of trendy Renaissance literary theory. And the impact both have had on Vickers the researcher can be seen throughout Shakespeare, Co-Author.

The book is divided into two parts. In the first, Vickers discusses the nature of playwriting in England during the Renaissance, in particular the common practice of collaboration, and then reviews the methods that have been used over the years to establish coauthorship. Part Two is an in-depth examination of Shakespeare's collaboration with four authors: George Peele (Titus Andronicus), Thomas Middleton (Timon of Athens), George Wilkins (Pericles), and John Fletcher (Henry VIII and The Two Noble Kinsmen). Most of the evidence presented here is internal, and shows how the lexical, metrical and poetic habits of the coauthors can be detected in the texts. In addition, Vickers devotes the final chapter to explicating how the discrepancies in plot and character in the five plays also indicate more than one author at work. The book also includes two appendices: one a collection of 
graphs from researcher Ants Oras's pioneering work into pause patterns in the plays of the period; the other a devastating critique of Foucault and his disciples called "Abolishing the Author? Theory versus History."

There is much to admire in Shakespeare, Co-Author. The introductory survey of playwriting practices, based on external evidence, is exhaustive and informative. The extensive methodological overview is clearly laid out and, while sometimes technical, easy to understand. Vickers's literature reviews for each play are models of the genre: they are thorough, critical, on the whole balanced, and they also nicely situate his own contribution. His data commentary on the more than 75 tables is also exemplary; student researchers, as well as publishing professionals, could learn something from studying Vickers's technique here. The arguments are solidly supported, and build over the course of the book. And where there are still any doubts about evidence, Vickers is not afraid to acknowledge them. In short, Shakespeare, Co-Author should convince most readers that these 5 plays were written in collaboration. Vickers's conclusions are palpable, and un-ignorable.

The methods used for detecting the composing habits of co-authors are both quantitative and qualitative, and derive in part from work carried out on the Beaumont and Fletcher canon, as well as the plays of Thomas Middleton. These include testing the verse (e.g., counting the number of feminine endings used); looking for parallel passages in other plays (by Shakespeare, his likely coauthor, as well as other candidates); documenting vocabulary and other linguistic preferences (some writers prefer you instead of $y e$, for example); and counting function words (like and, or, and $b u t$ ). The plays are also subjected to stylometric and socio-linguistic analyses, and their dating and chronology are investigated. On their own any one of these methods is not enough to establish co-authorship, but in combination they are very effective.

Vickers also demonstrates the value of conducting a full literature review, i.e. one that relies on scholarship published before 1975. He makes a point in his preface to emphasize that the work carried out in authorship studies during the 19th century is just as important as more recent work, and that the earlier work is often overlooked today. He argues that not reading - or fully understanding - this literature on collaboration has lead to 150 years of scholarship being either dismissed or ignored in critical editions of the five plays. For example, Vickers admonishes the editors responsible for recent individual editions of Titus Andronicus published by Arden, New Cambridge and Oxford.

Jonathan Bate, who edited Titus Andronicus for the Arden 3rd Series, is no 
exception. I had just finished reading his edition before picking up Shakespeare, Co-Author, and thought Bate had settled the authorship question once and for all when I read in his introduction that "[c]omputer analysis of [function words] suggests what literary judgement confirms: that the whole of Titus is by a single hand and that at this level of linguistic habit is very different from Peele's. According to Andrew Q. Morton, who undertook the analysis, the statistical probability of Peele's involvement is less than one in ten thousand million." 3

I was impressed by the figure of "one in ten thousand million," but Vickers was not. He recounts how Morton's research was later shown to be seriously flawed, and he takes Bate to task for not knowing - and reporting - this crucial information. He also criticizes the Arden editor for only spending 3 pages on the authorship question. (Vickers devotes 150 pages to Titus in his book.) The danger of such a slapdash editorial approach is that it has a knock-on effect: "Our collective understanding of Shakespeare, our need to distinguish his work from that of his co-authors, is not advanced by editors who treat the authorship question in such a partisan or perfunctory manner... The prestige that these major editions enjoy means that their pronouncements on the authorship issue can have a stultifying effect on other editors and critics. In the recent New Penguin edition the textual editor, Sonia
Massai, simply capitulated before Jonathan Bate's authority, reporting that 'Bate distances himself from [J. C.] Maxwell's view that the first act was written by George Peele. ..' as if no more need to be said. There, more than eighty years of scholarship by a dozen reputable scholars was buried from view by citing one of Shakespeare's 'conservators,' a deference which, on this issue, was unfortunately misplaced" (210).

Interestingly, Bate himself reviewed Shakespeare, Co-Author for the Times Literary Supplement, and was not afraid to be self-critical in the light of Vickers's stinging indictment: "I so wanted to praise the play ... that I uncritically accepted the arguments for solo authorship put forward both by usually trustworthy scholars and seemingly persuasive stylometricians brandishing computer printouts and big-number statistics. The profound methodological flaws of the latter have now been exposed and new research by MacDonald Jackson has been published which provides compelling evidence that the first act of the play was actually written by George Peele. Next time I edit Titus I will follow Vickers's example and credit it to 'William Shakespeare with George Peele.'" 4

Bate is not the only editor who has had his mind changed. Stanley Wells acknowledges Peele as co-author on the title page of the play in the second edition of the Oxford Complete Works. In 
his introduction Wells writes that recently "scholars [have] increasingly come round to the view that George Peele had a hand in, especially, the first act of the play." 5 There can be little doubt that he includes Brian Vickers among these scholars. And when asked to comment on Vickers's work, Stephen Greenblatt, the general editor of the Norton Shakespeare, said "I think the next edition ... should acknowledge the arguments for the collaborative nature of Titus." 6 That three highly regarded editors have gone on record so soon to recognize Vickers's accomplishment says much about the effect this book is having in the field: the results are quickly being disseminated to the general reader.

I do have some reservations about the book; one is methodological and the others are stylistic. The first is related to the manuscript of The Booke of Sir Thomas More, perhaps the most significant text in Shakespeare attribution studies. Throughout the book Vickers is at pains to point out that it is important to look at large chunks of text when trying to identify co-authors. This seems to me a sound and reasonable methodology. Yet some of the foundation work in the field has been carried out on Sir Thomas More, Shakespeare's contribution to which consists of a scant 185 lines of text (164 lines supposedly handwritten by Shakespeare himself; the rest in the hand of a scribe). While the evidence suggests - overwhelmingly that this is indeed Shakespeare's work, I am still somewhat troubled by so much being made of so few words. I would have welcomed more discussion on this point.

My other concerns are about Vickers the writer. On occasion his tone is too dogmatic; when taking on other researchers, for example, he can be particularly unmerciful in his criticism. While I believe there is nothing wrong with a writer taking a strong position, I also think this particular writer would win over more readers where he to tone down his sharp language in places. Another problem is that the book lacks a concluding chapter. From what I have seen Vickers's decision to forego a conclusion is not unique: writers across disciplines are doing the same nowadays. Whether they are doing this because they feel they have written enough already, or are under pressure from editors and publishers to save space, I think they are making a mistake. The closing gambit in any work can often be just as important as the opening one. It is a pity, therefore, that Vickers simply moves on from his chapter on plot and character to the two appendices, and does not round off his discussion with a final chapter that nicely complements his opening one.

Despite these reservations, this is an important work, and as mentioned above one that is already having an 
impact on the discipline. Shakespeare's conservators are not the only ones who will have to shift their paradigms because of Shakespeare Co-Author. The book shows that writers in the early modern period left their individual stamps on the plays, or the portions of the plays, they wrote, so the critics who for many years have advocated for the 'de-centered' author will also need to reconsider their post-modern positions. Despite the fact that theatre was (and is) a collaborative art, Renaissance authorship studies corroborate what external evidence like Henslowe's diary has always shown: playscripts were written by individuals. And the work these individuals created made it to the printing house, and to the page. Vickers should be celebrated for 're-centering' Renaissance authors.

This will not be the last word on collaboration, as there is an urgent need to extend Vickers's work to two other plays: Henry VI, Part 1 and Edward III. But these are more difficult cases because, like The Booke of Sir Thomas More, they probably involve more than two authors. For now, though, Shakespeare Co-Author is recommended reading for anyone interested in the collaborative practices of Elizabethan and Jacobean dramatists in general and the work of one author with his company of collaborators in particular.

\section{Tom Rooney}

Notes

1. 6 volumes; London and Boston: Routledge, 1974-81.

2. New Haven and London: Yale University Press, 1993.

3. Jonathan Bate, Introduction to Titus Andronicus, by William Shakespeare (London and New York: Routledge, 1995), p. 83.

4. Jonathan Bate, "In the Script Factory," Times Literary Supplement (18 April 2003), pp. 3-4.

5. Stanley Wells, "Introduction to Titus Andronicus," in Stanley Wells, Gary Taylor, et al. ed., William Shakespeare: The Complete Works, 2nd ed. (Oxford: Clarendon Press, 2005), p. 155.

6. William S. Niederkorn, "Seeing the Fingerprints of Other Hands in Shakespeare," The New York Times (2 September 2003), p. E1. 